\title{
Mobile Assisted Language Learning: Affordances and Limitations of Duolingo
}

\author{
Kyria Rebeca Finardi (Corresponding author) \\ Department of Languages, Culture and Education, Federal University of Espirito Santo \\ Avenida Fernando Ferrari, 514, Vitoria, ES Cep. 29075-910, Brazil \\ Roberta Gomes Leão \\ Federal University of Espirito Santo \\ Avenida Fernando Ferrari, 514, Vitoria, ES Cep. 29075-910, Brazil
}

Gabriel Brito Amorim

Post-Graduate Program of Linguistics (PPGEL), Federal University of Espirito Santo Avenida Fernando Ferrari, 514, Vitoria, ES Cep. 29075-910, Brazil

Received: August 3, 2016 Accepted: September 8, 2016 Published: September 11, 2016

doi:10.5296/elr.v2i2.9842ＵRL: http://dx.doi.org/10.5296/elr.v2i2.9842

\begin{abstract}
This study aimed at analyzing how mobile assisted language learning (MALL) may be used to aid second/foreign language (L2) learning. So as to reach this goal, the Duolingo platform, one of the most popular apps among L2 learners, was analyzed in terms of its possibilities and limitations for L2 learning as perceived by its users. With that aim, a study was carried out with 80 participants, 45 of whom were L2 learners who answered an online survey about their preferences for L2 learning, 25 MALL users and 10 L2 teachers who were interviewed. Data analysis used a mixed methods design with predominantly qualitative data. Results of the study showed that participants recognize the relevance of MALL for L2 learning and think that the Duolingo may aid L2 learning to a certain extent, but agree that a teacher is necessary to foster interaction and the development of production skills in L2. Based on these results the study concluded that L2 teachers should consider using blended approaches combining MALL in traditional classes.
\end{abstract}

Keywords: Mobile technology, MALL, Duolingo 


\section{Introduction}

The development of digital technology with its easy access to information has changed the way we communicate and relate with and in the world (Finardi \& Porcino, 2014). In the digital age (Lévy, 1999) we live in, teachers struggle to keep students, most of whom are the so called digital natives (Prensky, 2001) motivated with materials that can hardly compete with the amount of stimuli and information available in a simple click (Reily, 2012). Teachers who try to use digital technologies in their classes face another challenge, namely, drawing the line between entertainment and learning activities with digital tools and gadgets.

Mobile learning makes educational contents available in a flexible form in terms of time and place, changing the relationship between learning and learners (Boy \& Motteram, 2013). In the case of additional language (Note 1) (L2) learning, mobile devices used in mobile assisted language learning (MALL) have been seen as tools to guide users to an easy access to word meaning in digital dictionaries and free educational apps. MALL is becoming popular among people who are interested in learning an L2 and MALL applications have been used to learn vocabulary, to access grammar exercises, to improve writing skills and to increase reading comprehension (Finardi \& Prebianca, in press; Kim \& Kwon, 2012; Kulkuska-Hume, 2009; Lan, Sang, \& Chang, 2007).

Duolingo is an app used in MALL that offers many activities for practicing structural aspects of additional languages. It is available for free for smartphones and tablets and is also a social media which connects people who are learning languages, showing how advanced they are in relation to one another in the language chosen. This feature of Duolingo resembles a game and as such may engage learners through motivation and competition. The Duolingo platform also offers activities for language teachers to work with their students and it was selected for this study because of its affordances for independent and ubiquitous forms of learning. Given its possibilities, the present study aims at reflecting on the possibilities and limitations of Duolingo for L2 playful learning through technology to achieve what Arruda (2013) calls the erasing of boarders between learning and entertainment.

Research has already emphasized the importance of looking at the potential of technology for education (Blake, 2013; Finardi \& Porcino, 2014; Prebianca, Finardi, \& Cardoso, 2015), and how the attention of contemporary students is more likely to focus on visual and kinesthetic stimuli rather than on traditional stimuli because of the intensity of the contact students have with technology outside the class (Reily, 2012). Mobile devices are changing the relationship between content and learner and between learning and entertainment (Arruda, 2013), and they mediate interactions between technology and people (Kulkuska-Hulme, 2009).

MALL is considered a form of being close to learners' reality and a way of reinforcing a spontaneous learning process. In order to understand the potential of MALL and contribute to teachers' informed decisions regarding its use, this study aims to analyze affordances and limitations of MALL in general and of Duolingo in particular for L2 learning. With that aim, the study reviews studies on MALL and analyzes affordances and limitations of the Duolingo platform for L2 learning as perceived by L2 learners and teachers. 


\section{Review of the Literature}

Arruda (2013) suggests that it is better to analyze the effects of the use of technology in people's lives than in isolated contexts such as in social networks and the like. But, before delving into the concept of MALL, and how other researchers consider the role of Duolingo for L2 learning, it is important to understand how the presence of technology is affecting L2 learners and teachers in general.

\subsection{Technology and L2 Teaching/Learning}

Arruda (2013) states that schools and traditional methods are losing ground due to the easy access to information that technology offers, usually outside classroom walls. Arruda (2013) goes on to explain that entertainment gadgets (such as media players) are products of the media culture and society, geared at pleasure and offering a space to connect people (Debord, 1976, cited in Arruda, 2013). The connection afforded by technology has been appropriated for other purposes besides entertainment, as shown in the many popular social movements organized via social networks originally created for entertainment (Arruda, 2013; Finardi \& Porcino, 2016). Finardi and Porcino (2014) claim that access to internet changed the way people use, teach and learn languages in general and L2 in particular and it also changed the way people deal with and position themselves in relation to other people and issues in society.

Arruda (2013) claims that some media devices are not rightfully considered tools for learning since they do not always offer potential for learning despite their playful nature. Teixeira and Finardi (2013) investigated the incorporation of digital technologies in teaching practices in Brazil and concluded that the main obstacle for this incorporation lies in the critical use of technologies in teaching methodologies rather than in the access to technology as such. In the case of mobile learning, teachers still face many challenges in the incorporation of mobile phones and tablets and usually frown at the use of mobile devices in the classroom (Boy \& Moterram, 2013). Despite this resistance, technologies nowadays are not only developed for entertainment, but also for work, education and other aspects of social life not always incorporated by schools (Boy \& Moterram, 2013). In the case of mobile technologies, the multitask feature of mobile devices enables the access to many functions at the same time/place and so can be said to permeate all aspects of people's lives.

In Brazil, there was an economic opening of the national market to increase the production of microinformatic objects. This opening stimulated the production and distribution of computers in schools and succeeded in expanding the discussion about the implications of using computers in education. Another consequence of this opening was the expansion of teaching/learning strategies (Arruda, 2013). Dias and Bocorny (2014), claim that internet access has increased in Brazil, currently ranked the "fifth-largest contingent of internet users" (p. 47) and the second for Facebook users (Finardi \& Porcino, 2016), despite the cost of broadband wi-fi service there. Finardi, Prebianca and Momm (2013) claim that internet is a useful tool for L2 teachers, though not all institutions can afford institutional wi-fi service connection.

According to Dias and Bocorny (2014), Finardi, Prebianca and Momm (2013), and Fadini and Finardi (2015a, b), the internet offers a myriad of possibilities for L2 teaching/learning. However, Dias and Bocorny (2014) suggest that English as foreign language (EFL) teachers 
would rather work with online games than other activities such as puzzles or videoconferences because of limitations of time and computer facilities. All participating teachers in Dias and Bocorny's (2014) study agreed that there is a rich environment for English learning on the internet. It is easy to find teaching materials on the web and most teachers in Dias and Bocorny's study (2014) believe that it is possible to improve English skills by using the internet because students may be more motivated to use the internet. Differently to findings in Teixeira and Finardi (2013), most teachers in Dias and Bocorny's study (2014) claimed to know how to integrate internet resources in the classroom and said that they did not need training to improve internet literacy skills.

As can be seen in the scenario just described, mobile devices may offer more opportunities for students than other types of technology, mainly because of their portability, social interactivity, connectivity, individuality, among other aspects. When it comes to L2 learning, MALL offers immediate feedback as other teaching strategies mediated by computers (Attewell \& Webster, 2004; Chinnery, 2006; Soloway; Norris; Blumenfeld; Fishman; Krajcik \& Marx, 2001; Finardi |\& Prebianca in press). Moreover, "the mobile device acts as a bridge between different sites of learning, some of which are "formal" whilst others are more "informal" (Kulkuska-Hulme, 2009, p. 101).

\subsection{MALL}

In Boy and Motteram's (2013) study, mobile devices are considered a flexible form of learning which is altering the relationship between learner and learning. Yet, the incorporation of MALL demands a series of changes in learning and teaching. Boy and Motteram (2013) found that teachers have been using tablets and mobile devices in their classroom to practice vocabulary, motivate learners and teach curricula contents. However, Boy and Motteram (2013) observed that some teachers need to improve their management levels of these devices. It is not only related to the performance of use, but also to the fact that some students get easily distracted by games and other entertainment functions of their mobile devices. To counteract these negative effects, Boy and Motteram (2013) suggest that some teachers use the content of these games in their students' mobile devices to promote language learning and practice. Boy and Motteram (2013) conclude that it is important to analyze whether teachers are receiving effective training to deal with the potential that those devices may bring to classroom. As it is, the presence of teacher is still paramount for the teaching and learning with technology as it will be discussed later in this paper.

According to Kulkuska-Hulme (2009), it is still difficult to offer a definition for the term mobile learning, whether it is related to mobile devices or to the concept of learner mobility. But it is possible to assume that mobile learning can happen everywhere, and it is not determined by the classroom environment (Finardi \& Prebianca, in press). Although there is not an agreement about the definition of mobile learning, it is commonly agreed that it relates not only to mobility in terms of spatial position, but also to how this mobility affects time and space boundaries (Traxler, 2009; Kakihara \& Sørensen, 2002 cited in Kulkuska-Hulme, 2009).

Kulkuska-Hulme, Norris and Donohue (2015) suggest that teachers and learners shape the language learning process and that the presence of a teacher to guide learners in the activities is still very important. As it was observed in Finardi and Prebianca (in press), some users of MALL still feel the need for teacher mediation to complement and support their learning 
process. Moreover, learners need help to select what type of app is better for each learning purpose. This is one of the reasons why this study aimed at analyzing an app used in MALL from the point of view of teachers and students. Kulkuska-Hulme, Norris and Donohue (2015), also state that learners and teachers share responsibilities for the learning process and mobile devices strengthen this co-responsibility. Mobile devices help teachers make language learning meaningful because its features are easy to access (photos, videos, voice recordings, etc.) and they can be easily shared. Finardi and Prebianca (in press) add that MALL is a low-cost alternative with an expressive number of options to offer in terms of activities for L2 students. In Kim's (2013) study, most students showed preference for materials that did not require too much attention such as "light" materials that were short and contained some fun In general, participants preferred contents that offered many possibilities of use such as podcasts and news. Students in Kim's (2013) study also resorted to scaffolding devices such as dictionaries and bilingual scripts. Teachers can make use of MALL as an interface between learning and entertainment (Arruda, 2013; Finardi; Prebianca, in press). Kim's (2013) study also shows that people choose MALL for several reasons depending on their goals and reputation. In general, the apps chosen by students were related to grammar, vocabulary, proficiency tests, famous journals, etc. But, the absence of engaging elements such as timely or field-dependent information, or fun stories were one of the major factors for students to discontinue using the apps in MALL.

Kim's (2013) study showed that "In general, students seemed to prefer audio-lingual methods, such as repetition, memorization, or drill practice. Most of them took MALL as an activity for input building or fluency development" (p. 139). As pointed out by Finardi and Prebianca (in press), Finardi, Prebianca and Schmitt (2016) and Finardi, Prebianca, Schmitt and Andrade (2014), this may not be a matter of student preference but rather a matter of student option once most apps for L2 learning are very structural and lend themselves mainly for vocabulary and grammar building though, as pointed out by these authors, language development also requires interaction in the target language which is usually not afforded by most MALL apps.

\subsection{Duolingo}

It is not easy to design an app for a specific purpose. In the case of L2 learning it needs to give opportunities for social engagement, in order for it not to be disconnected from reality. Most of the apps developed for this purpose do not provide enough contexts according to the contents explored by them. (Culbertson, Wang, Jung, \& Andersen, 2016). Leffa (2014) claims that Duolingo was very successful in terms of design, but not in terms of adaptation for use in classroom by teachers and its methodology is not flexible enough to meet students' needs.

Duolingo is a free platform for L2 learning available in 19 languages, though it is not meant for the learning of all the 19 languages depending on the user's first language (L1). For instance, if a Portuguese speaker intends to learn Dutch as an L2, this speaker would have to use another language, for example English, as a bridge to have access to Dutch. As such, we can say that if a person has English as L1, he/she can choose any of the 19 languages to learn in Duolingo. The number and choice of languages a person can learn in Duolingo will depend, thus, on the users' L1 and the L2 he/she wants to learn. This platform is accessed through a website or an app for smartphones or tablets. It contains activities for reading, writing, listening and oral 
practice in the target language. In the end of each module the user wins a type of reward, such as a medal, that allows the user to advance to the next level.

Quadros (2014) considers the layout and the execution of the Duolingo lessons as a characteristic of gamification because of its ranking parameter for user performance displayed with progression bars and limited number of mistakes (3) indicated by 3 hearts. However, in the present study Duolingo is considered a form of MALL and not of game because the analysis carried out by Gunter, Campbell, Braga, Racilan and Souza (2016) showed that Duolingo does not match the game category, despite presenting features of a game. Culbertson, Wang, Jung and Andersen (2016) suggest that Duolingo uses this game features to keep users engaged according to the RETAIN (Relevance, Embedding, Transfer, Adaptation, Immersion, Naturalization) evaluation model (Gunter; Kenny, \& Vick, 2008 cited in Gunter; Campbell; Braga, Racilan, \& Souza, 2016). These authors observed the weakest and strongest aspects of this app, though the evaluation was somewhat affected in some points because the model used for the evaluation is meant for analyzing games for educational purposes not and not apps. In the Embedding category, for instance, Duolingo reached a very low score because this category measures the way that the fantasy/plot is integrated in the learning/game. Duolingo has neither fantasy nor plot to involve users during task execution and so cannot be considered strictly a game.

\section{Methodology}

The aim of this study is to reflect on affordances and limitations of MALL in general and of Duolingo in particular. With that aim, a mixed methods design (Dorney, 2007) was used to triangulate quantitative and qualitative data. Quantitative data were collected through an online questionnaire with close questions regarding the use of mobile technologies and L2 learning (Appendix I) (Note 2) sent to approximately 19.000 students of a federal university in Brazil and answered by 45 participants. Qualitative data were gathered through a questionnaire (Appendix II) with close and open questions answered by 25 participants that use mobile devices for L2 learning. Data were transcribed, coded and triangulated for the analysis of learners' perceptions. A second phase of the study involved the analysis of the activities proposed by Duolingo so as to answer the main research question of whether this app enables L2 learning only through human-device interaction. Finally, a third phase of the study was carried out with ten L2 teachers through an interview (Appendix III) to answer the other research question, namely: Are L2 teachers aware of the possibilities of using this app with their students? Results of the study will be reported separately first and then triangulated for data discussion.

\section{Analysis}

\subsection{Quantitative Analysis}

A questionnaire was built in Google forms and sent by email to almost 19,000 people in the academic community (students, professors and staff) of a Brazilian university and 45 participants answered it. Regarding the L2 learning profile of this population, only 17 of the 45 participants were studying an L2 at the time of data collection, 19 have already studied an L2 and 9 did not answer this question. 
Regarding participants preferred method for L2 learning, data shows that participants prefer to have face to face classes since $77,7 \%$ of participants checked this option while only $8,3 \%$ opted for the online method, and 38,8\% did not inform what was their preferred method for learning an L2. As suggested by Finardi, Prebianca and Schmitt (2016) one of the L2 learners' need is to have structured feedback with pedagogical orientation, in order to, avoid fossilization of errors and to find solutions to the problems presented in their production in the target language. This may be an indication for most people answered that still prefer the mediation of teachers in face-to-face interactions. However, it was also perceived that some participants checked the two options, corroborating suggestions in studies that analyzed students' perception of blended or hybrid approaches to L2 learning (for example, Prebianca, Finardi, \& Cardoso, 2015).

Data in this study corroborates data in previous studies that sought to analyze students' perceptions of hybrid or blended approaches to L2 teaching/learning (for example Finardi, Prebianca, \& Schmitt, 2016; Prebianca, Finardi, \& Cardoso, 2015; Prebianca, Vieira, \& Finardi, 2014; Silveira \& Finardi, 2016) where most people claimed to prefer a combination of traditional classes with face-to-face interactions and online activities with a total of $41,6 \%$ of participants marking this option in this study. A minority of $13,8 \%$ of participants use only the online method, and $38,8 \%$ of them claimed to study only in traditional face-to-face courses. These numbers show that L2 students might not feel confident about using only online resources to learn an L2 and may need the mediation of the teacher and face-to-face interaction so as to fully develop L2 skills, corroborating data in Finardi, Prebianca and Schmitt (2016).

Participants informed what kind of online courses they used to learn an L2. Since the research happened in a public university, most people claimed to use the My English Online (MEO) course, a free course offered by the English without Borders program. MEO helps students get a reasonable proficiency level in order to participate in internationalization programs. Besides MEO, participants mentioned only Duolingo, Livemocha, Babel and Bissu.

MEO was the option for $45 \%$ of the participants, while $40 \%$ checked that they use Duolingo. Livemocha, Bissu and Babel were mentioned, but were not popular in this academic community. Only $10 \%$ of the participants used Livemocha and $1 \%$ of them used Bissu and Babel. These results do not put in question the efficiency of these online courses; it might show that they just do not offer what this specific public is looking for. It is important to mention that MEO is not available in a mobile version as an app and since study focused on mobile learning, MEO was discarded and Duolingo was selected for this study.

The present study attempted to find out what scaffolding material students used as an extra help in their learning process. In order to narrow down the collected data, the survey inquired the types of translation tools participants used. The participants that never attended L2 classes were able to answer the question about translation tools together with the others who had. The participants mentioned only three translation tools: Google Translator, Linguee and Babylon. Google Translator was chosen by the vast majority, $88.8 \%$ of the participants while only $4 \%$ opted for Linguee and 1\% for Babylon suggesting that Google Translator is used by most of this population.

The study also attempted to find out whether participants used their mobile devices with Internet connection during L2 classes. Although learners seem to be aware of the possible uses of MALL, only a minority of participants in this study uses mobile devices in L2 classes. It 
reflects to the fact that the activities done inside the classroom are not requiring the use of those devices that are constantly present in students' context.

\subsection{Qualitative Analysis}

In order to triangulate data so as to broaden the analysis, an interview with 28 people was carried out so as to better understand their views on MALL. Only one participant claimed that he had never studied an L2 before. The other participants have already studied, or are now studying an L2. Twenty out of 28 participants mentioned English as the target language, followed by Spanish, and studied by 8 people and French and German with 5 participants each. Two participants studied Hebrew while Italian and Dutch were studied by one student, respectively.

When asked about the use of the internet in participants' L2 performance in class only 16 participants answered that they use the internet to solve doubts, study, practice conversation, translate words or sentences, and to do online exercises. Six participants answered that they only study on the Internet, and they are not enrolled in any face-to-face classes. Finally, 6 participants reported not using the Internet for L2 practice/learning.

The interview focused on the use of mobile devices by L2 users and results showed that 24 (out of 28) participants use their mobile devices to practice/learn an L2. These results indicated that the participants use more than one learning/practice option to improve L2 such as web dictionaries, translators and apps.

The participants used these resources for different reasons. Nine people indicated that they used MALL to study, 8 claimed to use MALL to increase vocabulary and 7 didn't mention the reason, 7 participants use MALL for translation, 6 to use it to communicate in social networks and one participant stated that he uses nothing. It recalls what was already enlightened by Kim (2013), that people choose the MALL according to their needs, goals and MALL's reputation. When participants were asked about how they had found out about those resources and 11 of them stated it had been through a friend. It emphasizes the idea that MALL's reputation has a high value for learners' choice. Other 9 people reported it had been in online search, 7 didn't mention how and one got the information about the resource through advertisements.

Most of the participants could not remember how long they had been using those resources in MALL. Among the ones who could, 6 of the participants were using MALL for less than 6 months, and 12 participants for one year or more. Seventeen participants stated that they believe in the efficiency of these resources while 10 participants didn't answer this question. One participant said that MALL is not efficient for L2 improvement and another participant added that MALL needs to improve voice recognition functions in cell phones in order to aid L2 learning more effectively.

Participants were also required to suggest ways in which MALL could be improved. Only 5 participants answered this question and stated that the most important improvement is in terms of real time conversation, 2 people said that MALL needs to improve their translation systems and dynamism, while providing offline access, better explanations, and options for monitoring activities. One participant mentioned that MALL needs to offer more security against viruses. 


\subsubsection{L2 Learner's Perceptions}

Participants were asked to express their opinion about the use of apps, technology and Internet to learn L2. Most of the participants interviewed said that the learning process through Internet resources would depend on the person. They pointed motivation, personal discipline and dedication as the features that enable people's learning without guiding. It can be seen in the excerpt below, translated for analysis:

P13: "...It is possible to learn in MALL as long as the person is motivated and disciplined to always study the language chosen. It is worth remembering that there are also free virtual classrooms. But if the person does not have discipline to study by him/herself the best way is to attend language classes in a traditional course."

It was also observed that some participants resisted the idea of a future where contents are learned only via Internet. Their speeches were based in the value of the interaction for learning. For these participants interaction is the major reason for L2 learning and so they believe that teachers play an important role in the learning process. They see the presence of the teacher as the form of mediation and guidance as can be seen in the excerpt below:

P3: “...These gadgets (referring to phones) must be seen as helpful tools but the experience inside a classroom is much richer. A classmate's doubt may contribute to others in the classroom. Besides that, teachers monitor the performance in exercises, the presence and the engagement in activities and conversations. In case the world reaches a future where kids learn everything through the internet and their online devices, we will be a robotized society, inhuman and it will be impossible to get work done in a team."

Yet, some participants believe that people can learn L2 only via MALL. They claimed that learning through MALL is something that is happening now around the globe and they did not deal with it as it were a future possibility only. These participants also mentioned that the flexibility of getting access to information contributed to the increase of autonomous learners in society.

P4: "The internet provides us with a huge contact with the language and the culture through websites and apps which give a huge support for students who are interested in learning. Currently, the number of self-taught people has increased a lot and surely the internet and its technologies act as a great facilitator in this process."

\subsubsection{L2 Teacher's Perceptions}

One of the aims of this study was to find out how teachers deal with the popularity of Duolingo among their students and whether they know the possibilities afforded by this platform for teachers. With that aim, an interview with two questions was carried out with ten English teachers. The first question in the interview was whether teachers encouraged students to use the Duolingo or not. The second question was whether they were aware of Duolingo's possibilities for teachers.

Results of this interview showed that only one teacher (T3) was aware of the possibilities of Duolingo for teachers and thinks it is possible to use this function with his students. T3 was in favor of using the app to recognize students' needs and preferences. It was clear that, although T3 did not use the Duolingo virtual class yet, the teacher is listening to the voice of the students. 
The other teachers were not aware of the possibilities of using Duolingo with their students. It was found that each teacher deals differently with the popularity of what is offered by the app.

T2: "I have already heard some students mentioning Duolingo, but, me, myself, have never taken time to see how it works; how the website is or how it is used. So, I can say that I don't encourage them to use Duolingo."

Most of the teachers interviewed agreed that the use of Duolingo is very helpful for their students. However, they instruct students to use it as a support and not as the only resource to learning. It shows that L2 teachers also perceive the efficiency of a blended or hybrid approach for L2 learning nowadays as suggested by Prebianca; Finardi; Cardoso, (2015). The following speech illustrate the general opinion of the teachers about Duolingo platform:

T5: Yes, I encourage my students to use Duolingo. I see that it works for me, so I always encourage them to log in and to study through it, and to use it to cope with the class content. I ask them not to stop, to keep studying here [at the language institution] and online too. I was not aware of the update, but I'll search about it, it sounds very nice.

\subsection{Discussion}

After reporting and triangulating the data in this study, it was noticed that the participants do not want to learn an L2 only through MALL. Most of the participants still prefer a combination of in person courses with the use of MALL. It was also perceived that teachers also do not orient their students to use MALL as the only resource of learning, but blend it with the class instruction. The need for teacher mediation in L2 learning is highlighted in many studies (for example Finardi, Prebianca, \& Schmitt, 2016; Prebianca, Finardi, \& Cardoso, 2015; Prebianca, Vieira, \& Finardi, 2014; Silveira \& Finardi, 2016; Finardi \& Prebianca, in press) and signals that the role of the teacher is by no means threatened by technology use and, moreover, learners need guidance as to select the resources which are best for their learning.

Duolingo was the most cited MALL app by the participants in this study. Though Duolingo has a clean layout, it does not offer opportunities for creative production or real-time conversations/interactions. Though Duolingo's website offers forums for discussing topics, such as how the app works, these forums are not organized for practicing L2 although Duolingo users can apply the rules about the language that should be used in the forums. Questions or statements in the forums run the risk of not being answered or being ignored by other users. Moreover, the disconnected sentences in Duolingo, is another disadvantage of this platform.

Although some users stated that people are learning only through MALL and quitting the classroom experience, specific aspects of L2 development, such as oral interaction, is not catered by this app. If such factors were to be considered, significant variations would be found from learner to learner and MALL to MALL. The current study considered the potential benefits of using MALL for the development of L2, and it was suggested that Duolingo can only reinforce structural and lexical aspects of language, but not language in use. That aspect of Duolingo requires another scaffolding device as a complement or a teacher supervision to explore communication, interaction, pragmatics and other aspects of L2 communication. Most of L2 teachers interviewed recognized the importance of the app as a booster for vocabulary and grammar learning, but they did not recommend using it as the only resource for L2 learning, 
they emphasize to students that Duolingo should be seen as a complement rather than as a course.

Another issue observed was that most teachers interviewed were not aware of the Duolingo possibilities for teachers. Moreover, some of them had never tested the app even after they heard about it through their students. If these teachers do not know how Duolingo works, how can they encourage and instruct students about its use? That is a confirmation of the loss in the centrality of the school in contemporary society (Arruda, 2013) because teachers may not be aware of what sources their students are accessing in order to engage in L2 learning. As reported by Boy and Motteram (2013), this might be a result of teachers' lack of training to use the technological artifacts currently available.

This position was clearly expressed in the speech of the learners interviewed that stated that the development of a language only through MALL is not a possibility for the near future but a reality for our society nowadays. Because of their experience with MALL, these learners could state that the number of self-taught learners is increasing.

Teachers should not resist the possibilities afforded by the Internet; instead they should work with it to afford more opportunities for learning by filling in the gaps of MALL in terms of feedback and interaction. As it was well observed by some users of MALL, interaction is a key factor for language learning and cannot be left out. For them, the presence of a teacher can guide learners to a better direction, so students can follow a clear path among the amount of information that they can find in the Internet and MALL.

\section{Conclusions}

This study aimed at analyzing affordances and limitations of the Duolingo platform. Results of the study suggest that Duolingo fosters vocabulary and grammar development. However it fails to develop language development in a broader sense because of its lack of interaction and contextualized language production. The L2 learners who participated in the study highlighted the possibility of learning an L2 only through mobile devices, though they claim that the presence of a teacher is still relevant to foster interaction and to guide them in their learning process. Teachers were not as enthusiastic about the possibilities of MALL in general and of Duolingo in particular for L2 as the L2 learner participants.

Society has reached a point that it is not possible to avoid the presence of technology and through this study, it was possible to see that MALL should be seen a complement rather than as single solution for L2 learning. MALL is in the increase and so language teachers should listen to their students' voices, helping them use MALL to boost L2 practice engaging learners in L2 classes through the use of MALL in blended approaches.

Platforms such as Duolingo, for example, offer possibilities for L2 learners to use activities oriented by a teacher. However, the fact that only one teacher participant was aware of this update and had never experienced it, shows that maybe teachers are losing opportunities to combine MALL with their classes. Because Duolingo does not provide a space for interaction with other L2 speakers in real time, teachers could fill in this gap by creating Whatsapp, Facebook, Skype groups that allow instant messaging through mobile devices.

Hence, this study showed that despite the potential of MALL in general and Duolingo in particular, there is still room for improvement and adaptation to use mobile devices out of class 
and inside classes as additional support to L2 learning. Overall, schools and teachers need to find their place among this new connected and mobile reality to promote interaction and learning in and with MALL.

\section{References}

Arruda, E. P. (2013). Ensino e aprendizagem na sociedade do entretenimento: desafios para a formação docente. Educação (PUCRS. Impresso), 36, 232-239.

Attewell, J., \& Webster, T. (2004). Engaging and supporting mobile learners. In Proceedings of MLEARNING 2004: Mobile learning anytime everywhere (pp. 15-20). London, UK: Learning and Skills Development Agency.

Blake, R. J. B. (2013). Brave New Digital Classroom: Technology and Foreign Language Learning. Washington, USA. Georgetown University Press.

Boy, I., \& Motteram, G. (2013). Does mobile learning need to move? In: Global perspectives on Computer-Assisted Language Learning. Glasgow: GB. pp. 32-35.

Chinnery, G. (2006). Emerging Technologies - Going to the MALL: Mobile Assisted Language Learning. Language Learning \& Technology, 10(1), 9-16.

Dias, I. C. B., \& Bocorny, A. E. P. (2014). Perceptions and Perspectives on Internet Assisted Language Teaching by English Teachers from Rio Grande do Sul. Entrelinhas (UNISINOS. Online), 8(1), 58.

Dornyei, Z. (2007). Research Methods in Applied Linguistics: Quantitative, Qualitative and Mixed Methodologies. Oxford: Oxford University Press.

Duolingo. (2015). Retrieved from https://www.duolingo.com

Fadini, K., \& Finardi, K. R. (2015a). Affordances of Web 2.0 Interfaces for the Teaching/Learning of L2 in the Flipped Classroom. In: International Conference of Education, Research and Innovation, 2015, Sevilha. ICERI 2015 Proceedings. Madri: Iated, 1, 1052-1058.

Fadini, K., \& Finardi, K. R. (2015b). Web 2.0 Tools for the L2 Class and Beyond. In END 2015 - International Conference on Education and New Developments, 2015, Porto. Proceedings. Lisbon: World Institute for Advanced Research and Science (WIARS), 1, 603-607.

Finardi, K. R., \& Porcino, M. C. (2014). Tecnologia e Metodologia no Ensino de Inglês: Impactos da Globalização e da Internacionalização. Ilha do Desterro, 66, 239-284. http://dx.doi.org/10.5007/2175-8026.2014n66p239

Porcino, M. C., \& Finardi, K. R. (2016). Construção de cidadania por meio do ensino de língua estrangeira e do letramento digital: uma proposta de WebQuest. ANTARES: Letras e Humanidades, 8(15), 144-166.

Finardi, K., \& Prebianca, G. (In press). Mobilidade e Ensino-Aprendizagem de Línguas Estrangeiras. Revista Polifonia.

Finardi, K., Prebianca, G., \& Momm, C. F. (2013). Tecnologia na Educação: o caso da Internet e do Inglês como Linguagens de Inclusão. Cadernos do IL, 46, 193-208.

Finardi, K. R.; Prebianca, G. V. V., Schmitt, J., \& Andrade, D. F. (2014). Technology, English Language Teaching and Internationalization at a Crossroad: Insights From The Analysis of a 
Virtual Learning Environment In Brazil. In International Conference of Education, Research and Innovation, 2014, Sevilha. ICERI2014 Proceedings. Madri: IATED, 1, 1-12.

Finardi, K. R., Prebianca, G. V. V., \& Schmitt, J. (2016). English Distance Learning: possibilities and limitations of MEO for the Flipped Classroom. Revista Brasileira de Linguistica Aplicada, 16, 181-208. http://dx.doi.org/10.1590/1984-639820158527

Gunter, G., Campbell, L., Braga, J., Racilan, M., \& Souza, V. (2016). Language learning apps or games: an investigation utilizing the RETAIN model. Revista Brasileira de Linguistica Aplicada, 1-29. http://dx.doi.org/10.1590/1984-639820168543

Kim, H. (2013). What to Consider for Effective Mobile-Assisted Language Learning: Design Implications from an Empirical Analysis. In Global Perspectives on Computer Assisted Language Learning. Glasgow - GB, pp. 138 -159.

Kim, H., \& Kwon, Y. (2012). Exploring smartphone applications for effective mobile-assisted language learning. Multimedia-Assisted Language Learning, 15(1), 31-57.

Kukulska-Hulme, A., \& Traxler, J. (2005). Mobile learning: a handbook for educators and trainers. Open and Flexible Learning Series. London, UK: Routledge

Kukulska-Hulme, A. (2009). Will mobile learning change language learning? ReCALL, 21(2), 157-165. http://dx.doi.org/10.1017/S0958344009000202

Kukulska-Hulme, A., Norris, L., \& Donohue, J. (2015). Mobile pedagogy for English language teaching: a guide for teachers. London, UK: British Council.

Leffa, V. J. (2014). Gamificação adaptativa para o ensino de línguas. In Congresso Ibero-Americano de Ciência, Tecnologia, Inovação e Educação. Buenos Aires. Annals, pp. $1-12$.

Lévy, P. (1999). tradução de Irineu da Costa. Cibercultura. São Paulo.

Lan, Y., Sung, Y., \& Chang, K. (2007). A Mobile-Device-Supported Peer-Assisted Learning System for Collaborative Early EFL Reading. Language Learning and Technology, 11(3), 130-151.

Merwe, A. V. D., Bozalek, V., Ivala, E., Nagel, L., Peté, M., \& Vanker, C. (2015). Blended learning with technology. In: Kilfoil, Wendy (Ed.). Moving beyond the hype: A contextualised view of learning with technology in higher education (pp. 11-15). Pretoria: Universities South Africa.

Prebianca, G., Finardi, K. R., \& Cardoso, G. (2015). Ensino-aprendizagem em contextos híbridos: o que pensam os alunos sobre o uso da tecnologia em aulas de inglês no ensino médio integrado. Caminhos em Linguística Aplicada, 12, 95-119.

Prebianca, G. V., Santos Jr., V. P., \& Finardi, K. R. (2014). Analysis of an educational software for language learning: insights from the Theory of Structural Cognitive Modifiability and Human-Computer Interaction. DELTA. Documentação de Estudos em Linguística Teórica e Aplicada (PUCSP. Impresso), 30, 95-114.

Prebianca, G., Vieira, M. F. V., \& Finardi, K. (2014). Instrução gramatical na era da tecnologia: investigando diferentes abordagens para o ensino-aprendizagem de Inglês no Ensino Médio Integrado. Signum: Estudos da Linguagem, 17, 181-214. http://dx.doi.org/10.5433/2237-4876.2014v17n1p181 


\section{Macrothink}

Prensky, M. (2001). Digital natives, digital immigrants, part II: do they really think differently? On the Horizon, NCB University Press, 9(6).

Prensky, M. (2005). What can you learn from a cellphone? Almost anything! Innovate, 1(5). Retrieved from http://www.innovateonline.info/index.php?view=article\&id=83

Quadros, G. B. F. de. (2014). Análise sobre o ensino de línguas em ambientes virtuais gamificados. In: (XI EVIDODOL/VIIICILTEC-Online) Encontro Virtual de Documentação em Software Livre e VIII Congresso Internacional de Linguagem e Tecnologia Online, 2014, Belo Horizonte. Encontro Virtual de Documentação em Software Livre e Congresso Internacional de Linguagem e Tecnologia Online.

Reilly, P. (2012). Understanding and Teaching Generation Y. Retrieved from https://americanenglish.state.gov/files/ae/resource_files/50_1_3_reilly.pdf

Silveira, N., \& Finardi, K. R. (2016). Hybridizing L2 Learning: Affordances of the Inverted Class Approach with Online Tasks. In Mafalda Carmo. (Org.). Education Applications \& Developments II Advances in Education and Educational Trends Series (Vol 2, pp. 91-100). 1ed.Porto: In Science Press.

Soloway, E., Norris, C., Blumenfeld, P., Fishman, B., Krajcik, J., \& Marx, R. (2001). Log on education: Handheld devices are ready-at-hand. Communications of the ACM, 44(6), 15-20. http://dx.doi.org/10.1145/376134.376140

Teixeira, D., \& Finardi, K. R. (2013). TICs No Ensino Presencial: Evidências de um Curso de Formação Continuada na Universidade Federal do Espírito Santo. Revista (Con) Textos Linguísticos (UFES), 7, 79-96.

Vesselinov, R., \& Grego, J. (2012). Duolingo effectiveness study. Retrieved from http://static.duolingo.com/s3/DuolingoReport_Final.pdf

\section{Appendix I}

Pesquisa sobre Tecnologia Móvel e Aprendizagem de Inglês

Informe o seu gênero

( ) $\mathrm{F}(\quad) \mathrm{M}$

Informe sua idade

( ) entre 20 e 25 anos

( ) entre 26 e 35 anos

( ) entre 36 e 45 anos

( ) mais de 46 anos

Informe sua situação neste IES

( ) Aluno

( ) Professor 


\section{Macrothink}

( ) Técnico Administrativo

Você estuda alguma língua estrangeira? Caso afirmativo indique qual ou quais.

( ) Sim. Estudo

( ) Não

Caso estude ou tenha estudado alguma língua estrangeira na universidade, indique onde estudou(a).

( ) Centro de Língua da instituição

( ) NucLi do programa Inglês sem Fronteiras

( ) Curso particular

( ) Curso online

Caso já faça ou já tenho feito algum curso de língua estrangeira online, indique qual foi e caso tenha feito mais de um, marque todas as alternativas que se aplicam ao seu caso.

( ) Duolingo

( ) My English Online (MEO)

( ) Outro. Qual?

Você usa algum site de tradução na internet? Caso use mais de um, marque todas as alternativas que se aplicam a seu caso.

( ) Google Translator

( ) Babylon

( ) Outro. Qual?

Você fala alguma língua estrangeira? Caso afirmativo indique qual ou quais. *

( ) Sim, falo

( ) Não.

Você usa tablet ou telefone celular com conexão à internet para fins acadêmicos? Caso afirmativo, indique os sites/aplicativos que mais usa.

( ) Não

( ) Sim, uso.

Você já participou de algum programa de intercâmbio estudantil? Caso afirmativo indique qual ou quais.

( ) Sim. Participei do programa e fui para (país)

( ) Não. 


\section{Macrothink}

Caso faça aulas de línguas estrangeiras, você usa o tablet ou telefone celular com conexão à internet durante as aulas?

( ) Sim

( ) Não

Indique aqui os sites/aplicativos que mais usa

Link for the raw data https://docs.google.com/spreadsheets/d/1cUviz5TB38M_HviDyY1ycZJ7xCs9cB8kIl6BiAHv ilw/edit?usp=sharing

\section{Appendix II}

Gênero:

Idade:

Qual sua profissão/curso?

Você estuda ou já estudou recentemente alguma língua estrangeira?

Qual idioma estuda ou estudou recentemente?

No seu curso de idiomas você utiliza a internet em algumas atividades propostas? Caso sim, explique em que situações a internet é utilizada.

Você possui algum dispositivo móvel como smartphone ou tablet?

Caso sim, você utiliza algum desses dispositivos para estudar e/ou praticar a língua estrangeira na qual você está se aperfeiçoando?

Caso você faça uso desses dispositivos móveis para estudar uma língua estrangeira, indique quais aplicativos você utiliza. Indique também quais os tipos de atividades que você realiza com o uso de tais aplicativos. 


\section{Macrothink}

Como você conheceu os aplicativos que utiliza para estudar a língua estrangeira? Há quanto tempo os utiliza?

Como você avalia os aplicativos que utiliza? Você acha que são úteis para o aprendizado da língua estrangeira? Por quê?

Você acredita que os aplicativos possam ou devam ser melhorados? Como?

$\mathrm{Na}$ sua opinião, os avanços tecnológicos como a internet, os dispositivos móveis e os novos aplicativos para estes dispositivos podem contribuir para o aprendizado de uma língua estrangeira sem a necessidade de frequentar cursos presenciais? Explique.

Link for the raw data of learners' view: https://docs.google.com/document/d/1dSZrs7n4Gsgv3TyJoBCjhUwbh7I2pFpZwrMvYciIs5 Y/edit?usp=sharing

\section{Appendix III}

Entrevistas com professores de L2

Você incentiva seus alunos a usarem o Duolingo?

Você estava ciente da nova expansão do Duolingo para professores e que neste espaço é possível inscrever seus alunos para formar uma sala de aula virtual com as atividades da plataforma?

Link for the raw data of teachers' interview with transcriptions: https://docs.google.com/document/d/1XPOwGHBWK1ucxuaDM7YsA8nmtbSpNscBhOPD KX3DiZk/edit?usp=sharing

\section{Notes}

Note 1 . In this work the term additional language is used to refer to any language but the first or native language (L1).

Note 2. The surveys of this study were made in Brazilian Portuguese, the native language of the participants. Given the amount of data collected, the appendices were not translated to English and link for an online document with the transcriptions is available at the end of each appendix. 


\section{Macrothink

\section{Copyright Disclaimer}

Copyright reserved by the author(s).

This article is an open-access article distributed under the terms and conditions of the Creative Commons Attribution license (http://creativecommons.org/licenses/by/3.0/). 